\title{
Literasi Media: Preferensi Warga Negara Muda di Era Disrupsi
}

Yakob Godlif Malatuny ${ }^{1}$, Julianus Labobar, Bernard Labobar

Sekolah Tinggi Pendidikan Agama Kristen Protestan Negeri Sentani, Indonesia 19godliefmalatuny15@gmail.com

\begin{abstract}
ABSTRAK
Era disruspi memperlihatkan kecanggihan teknologi informasi yang berdampak pada gaya interaksi warga negara muda. Namun muncul persoalan baru yang semakin kompleks, yaitu banyaknya kejahatan dengan menggunakan kecanggihan teknologi informasi itu. Artikel ini menjelaskan pentingnya literasi media bagi warga negara muda di era disrupsi. Pendekatan yang digunakan dalam penelitian ini adalah kualitatif dengan menggunakan metode studi kasus, sementara teknik pengumpulan data berupa wawancara, observasi, dan studi dokumentasi. Hasil penelitian menunjukkan pemenuhan kebutuhan informasi dan gaya interaksi warga negara muda telah bergerak mengikuti kecanggihan teknologi informasi di era disrupsi. Mengakses berita online, mempelajari riset terbaru, menonton khotbah adalah pilihan-pilihan bebas warga negara muda. Jaminan kebutuhan informasi dan gaya interaksi yang sehat bagi mereka adalah literasi media. Literasi media melatih kemampuan mereka untuk menginterpretasi, menganalisis, dan mengevaluasi informasi secara benar. Jadi, literasi media menjadi preferensi mereka untuk melihat dengan lebih tajam kebenaran pesan di media, kemudian mengkritisi jika dianggap mengandung resiko. Maka, diharapkan kepada mereka yang hidup di era disrupsi agar mempelajari pengetahuan tentang literasi media.
\end{abstract}

Kata kunci: literasi media, preferensi warga negara muda, era disrupsi

\section{ABSTRACT}

Disruption era reveals the sophistication of information technology that has an impact on the the interaction style of the young citizens. However, an increasingly complex new problem arises; a high number of crimes using the sophistication of information technology. This article explains the importance of media literacy for young citizens in the disruption era. The approach used in this research was qualitative using a case study method, while data collection techniques include interviews, observation, and documentation studies. The results show that the fulfilment of information needs and interaction styles of young citizens have been shifting to the use of information technology in the era of disruption. Accessing online news, learning the latest research, watching sermons are the free choices for young citizens. For them, guaranteed information and a healthy interaction style is media literacy. Media literacy exercises their ability to interpret, analyze, and evaluate information correctly. Therefore, media literacy can be their preference to see more sharply the truth of the messages in the media, even to criticize if it is considered risky. So, those living in the era of disruption are expedted to learn the knowledge of media literacy.

Keywords: media literacy, youth citizen preference, disruption era

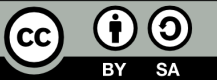

This work is licensed under the Creative Commons Attribution-ShareAlike 4.0 International License. (C2020 by the author(s). 


\section{PENDAHULUAN}

Era disruspi atau era industri 4.0 menginisiasi lahirnya gaya interaksi baru yang lebih kreatif, inovatif, dan masif. Interaksi ini didukung oleh kemajuan informasi dan teknologi canggih. Setiap peristiwa yang terjadi di setiap belahan dunia dapat disaksikan secara bersama-sama oleh warga negara sejagat dalam detik yang sama di tempat yang berbeda-beda. MacLuhan (1964), menggambarkan bahwa dunia menjadi semakin sempit karena teknologi elektronik dan arus informasi yang sama derasnya ke setiap belahan dunia. Artinya, secara radikal arus teknologi informasi turut mengubah struktur kehidupan sosiologis.

Bentuk-bentuk interaksi, terutama cara-cara menyampaikan pesan, opini, kritik, dan evaluasi berubah secara radikal (Goldsmith et al., 2017; Ohoitimur, 2018). Kecepatan informasi dan teknologi mendekatkan kebudayaan-kebudayaan yang terasing dan saling berbaur. Dunia yang luas menjadi padat. Tercipta jaringanjaringan sosial yang menjadi katalisator bagi perubahan sosial. Dalam konteks zaman itu, akhir abad ke-20 mulai berkembang "e-commerce" yang menyebabkan kegiatan-kegiatan komersial menjangkau seluruh belahan dunia.

Selain menciptakan aspek positif yaitu "global village", teknologi informasi juga memunculkan aspek negatif. Banyak terjadi kejahatan dengan menggunakan teknologi informasi tersebut. Perang kata-kata, ketidakadilan, dan kriminalitas sedang terjadi akhir-akhir ini. Artinya, muncul persoalan yang semakin kompleks. Namun, sebagian kalangan membaca perkembangan teknologi canggih ini sebagai kekacauan sosial yang dapat mengubah dunia industri barang dan jasa. Fenomena ini digambarkan oleh Christensen dan Fukuyama sebagai "disruption" dengan paham yang berbeda-beda.

Christensen (2006) memahami disrupsi sebagai peluang inovasi yang menguntungkan sementara Fukuyama (2000) beragumen bahwa disrupsi adalah gangguan terhadap tata sosial. Akan tetapi, terdapat kesamaan pikiran kedua tokoh ini soal konteks zaman yang sama ketika teknologi informasi mulai mencapai kemajuan yang definitif dan dengan cepat mempengaruhi pola-pola relasi dan komunikasi (Ohoitimur, 2018). Hasilnya, semakin meningkatnya pengguna internet atau media sosial di seluruh dunia. Interaksi dan penyebaran informasi dapat tersebar cepat melalui media. Fenomena ini tentu menghasilkan peluang sekaligus tantangan bagi seluruh warga. Penegasan ini beralasan karena muncul beberapa persoalan mendasar.

Kesatu, kepentingan politik telah diseludupkan melalui berita yang dipublikasikan ke media. Para pemain politik memaksimalkan keuntungan berita. Di sini, media lebih bertanggung jawab kepada pemilik kepentingan daripada penyampaian informasi yang sehat kepada warga. Terhadap persoalan itu, Prasetiyo (2016) menghasilkan kajian bahwa kepentingan politik telah mencemarkan peran media sehingga beragam berita menguntungkan pihak tertentu dan mendapat porsi besar dalam pemberitaan. Idealitas media yang bertugas memproduksi kebenaran informasi berbanding terbalik dengan realitas akhir-akhir ini. Media yang sepatutnya digunakan sebagai wahana untuk menginformasikan fakta yang sahih kepada warga, malah dieksploitasi untuk mewujudkan kepentingan politik kelompok tertentu. 
Kedua, kemunculan hoaks di media yang tidak terbendung dapat meresahkan banyak warga. Tanpa disadari hoaks mengaktifkan kepentingan kelompok tertentu, namun menonaktifkan akal sehat warga. Data menujukan setiap tahun hoaks mengalami peningkatan. Mengacu pada data Kementerian Komunikasi dan Informasi (Kemenkominfo) pada tahun 2016, hoaks mencapai angka 2700 sementara tahun 2017 terdapat sekitar 800.000 situs yang terindikasi menyebarkan informasi bohong. Sebuah survei yang dilakukan oleh Masyarakat Telematika (Mastel) menunjukan bahwa sepanjang bulan Februari tahun 2017 hoaks telah menjadi persoalan nasional yang berdampak negatif pada keutuhan bangsa, ketidakstabilan konstelasi politik, menganggu keamanan dan kenyamanan warga. Kondisi ini sangat berpotensi menghambat kemajuan pembangunan negara.

Pada tahun 2018, riset DailySocial dan Jakpat Mobile Survey Platform terhadap pengguna smartphone di seluruh Indonesia terkait penyebaran hoaks menemukan bahwa informasi bohong ini paling banyak tersebar pada media sosial yaitu Facebook, WhatsApp, dan Instagram. Responden yang tidak memiliki kecakapan untuk mendeteksi hoaks mencapai angka $(44,19 \%)$, sementara responden sisanya $(51,03 \%)$ bersikap pasif dan tidak percaya saat menerima hoaks.

Mengacu pada statistik maka hoaks telah menimbulkan "chaos". Pilihan etik oknum jurnalis dalam memproduksi berita di media diatur secara teknis demi mewujudkan kepentingan tertentu. Perilaku yang benar secara moral dari jurnalis diabaikan dengan tujuan mengambil keuntungan dari penyebaran hoaks. Terhadap persoalan ini, tanggung jawab warga negara dituntut aktif mengkritisi pihak media. Sebab, ketidakhadiran kontribusi pikir setiap warga negara terhadap agenda media akan menghasilkan "catastrophe" (Rahmawati, 2015).

Ketiga, reputasi media di Indonesia mengalami penurunan. Kondisi ini ditandai dengan menurunnya tingkat kepercayaan warga terhadap media. Sebuah survei yang dilakukan oleh Edelman Trust Barometer mengonfirmasi hal tersebut. Pada tahun 2015 ukuran kepercayaan warga terhadap media berada pada angka 63 persen sementara tahun 2016 sebanyak 68 persen. Penurunan kepercayaan warga terhadap media sebagai respon terhadap maraknya hoaks, dijadikan sebagai alat politik, dan penerbitan informasi yang kurang berkualitas.

Keempat, hoaks diproduksi untuk menambah penghasilan oknum jurnalis. Persaingan antar berita di media telah menarik kepentingan pasar "market oriented". Pihak media memainkan peran untuk mengutamakan mereka yang membiayai peliputan berita daripada kebutuhan informasi yang sehat bagi warga. Data yang dikutip dari Tirto.id (2016) menunjukkan bahwa selama tahun 2016 media yang sukses memproduksi berita hoaks menghasilkan keuntungan sebanyak 25 juta rupiah setiap bulan. Temuan Sen dan Hill (2001), dalam sebuah penelitian menunjukkan bahwa peran media di Indonesia telah beralih dari merefleksikan realitas menjadi merepresentasikan realitas. Karena itu, media dapat dijadikan sebagai alat untuk mewujudkan "market oriented".

Kelima, kondisi darurat literasi sedang dialami oleh sebagian besar warga negara muda. Tanggung jawab pendidikan yang belum maksimal dalam meningkatkan pengetahuan literasi media pada setiap jenjang adalah salah satu indikator penyebab kondisi dimaksud. Murdiono (2014) menjelaskannya dalam 
suatu konsep “tidak ada upaya untuk meningatkan literasi media sama dengan membiarkan kejahatan dan pembodohan terus berlangsung di depan mata". Lebih dari itu, Prasetiyo (2016) menekankan dukungan yang optimal dari sektor pendidikan terhadap berbagai akses informasi benar akan menghasilkan nilai SDM yang unggul bagi warga negara muda. Sebaliknya, bila mereka belajar dari sumber media yang keliru dan menyerap informasi palsu, maka tentu potensi besar mereka menjadi sia-sia. Kekacauan pikiran yang tidak dapat dipulihkan (irreversible dagame) bisa menimpa mereka. Karena itu, sejak tahun 2007 The Education Testing Service (ETS) telah mengambil langkah untuk mempromosikan literasi media yang terdiri dari kecakapan mengakses informasi, mengorganisasi, menilai kualitas, relevansi, dan manfaatnya.

Keenam, pemilihan topik dalam tulisan ini bukanlah penelitian awal, tetapi menjadi penting sebab subjeknya berbeda dengan yang sebelumnya. Mahasiswa program studi Pendidikan Pancasila dan Kewarganegaraan (PPKn) Universitas Pattimura dipilih sebagai subjek. Argumen dasarnya adalah isu-isu kewarganegaraan terkait dengan keilmuan PPKn yang diterima lewat media dapat dijadikan sebagai salah satu sumber pengetahuan. Lebih dari itu, mereka adalah elemen generasi muda yang mesti mendapat perhatian serius. Suryadi (2007) menjelaskannya dalam suatu konsep "masa depan kehidupan bangsa digantungkan di pundak generasi muda". Karena itu, setiap warga negara muda (young citizen) mesti dibekali dengan pengetahuan tentang literasi media.

Berita di media ibarat jendela bagi mereka untuk melihat kejadian yang terjadi di luar. Di sini, literasi media diperlukan sebagai jendela pengetahuan untuk melihat secara jernih berbagai informasi yang diproduksi ke media. Buckingham (2001), beragumen bahwa literasi media digunakan untuk menyiapkan mereka yang muda dari sebaran informasi di media. Jadi melalui literasi media setiap "young citizen" dapat menjadi konsumen media yang berdaya hidup di era disrupsi.

Menjadikan literasi media sebagai preferensi bagi mahasiswa PPKn sebagai warga negara muda adalah langkah penting yang mesti diupayakan. Sebab Shrum (2010), melalui teori subliminalnya menekankan dampak media dapat ditelusuri dari teori pesan. Pesan atau stimulus yang diserap oleh persepsi dan alam otak bawah sadar yang diterima melalui medium gambar yang diulang-ulang akan menimbulkan dampak yang efektif. Pesan atau stimulus ini cepat melintas sebelum seseorang dapat memprosesnya lalu perlahan-lahan mempengaruhi dan mengubah pikiran sadar manusia.

Mengingat begitu urgen literasi media bagi warga negara muda di era disruspi, maka topik dalam tulisan ini menjadi penting dan menarik untuk dibahas. Sebab, keyakinan penulis bahwa akan terjadi persoalan baru bagi warga negara muda bila tema ini tidak segera dikaji melalui sebuah penelitian ilmiah untuk mendapatkan cara pemecahannya.

\section{METODE PENELITIAN}

Pendekatan yang digunakan dalam penelitian ini adalah kualitatif dengan menggunakan metode studi kasus. Pendekatan ini dipilih untuk menghasilkan data akurat, mendalam, dan komprehensif yang berkaitan dengan tema penelitian. 
Lokasi penelitian adalah Universitas Pattimura Ambon. Informan dalam penelitian ini adalah mahasiswa PPKn Universitas Pattimura semester dua, empat, dan enam pada tahun akademik 2018-2019 yang berjumlah 30 orang.

Peneliti menggunakan teknik wawancara secara mendalam, observasi, dan studi dokumentasi berupa pengumpulan data-data atau dokumentasi yang berkaitan dengan tema penelitian ini. Sementara teknik analisis data menggunakan tahapan yang dirumuskan Miles dan Huberman (2014), yaitu (1) reduksi data, (2) sajian data, (3) penarikan kesimpulan dan verifikasi untuk menjelaskan data penelitian terkait literasi media sebagai preferensi bagi warga negara muda di era disrupsi.

\section{HASIL PENELITIAN DAN PEMBAHASAN Berselancar di Era Disrupsi}

Kesadaran hidup dari mahasiswa PPKn Universitas Pattimura telah mengubah gaya interaksi dan penyerapan informasi di era disrupsi. Peningkatan kemampuan beradaptasi pada perubahan yang sedang berlangsung merupakan upaya yang dilakukan secara terus menerus, sebab mereka tidak ingin terbawa arus perubahan.

Pemenuhan kebutuhan informasi dan gaya interaksi warga negara muda telah bergerak mengikuti kecanggihan teknologi. Kondisi ini ditandai dengan penggunaan telepon seluler. Awalnya alat ini hanya mempunyai fitur suara atau teks. Namun sekarang telah dilengkapi fitur suara, teks, dan gambar yang dapat diakses dalam satu aktivitas sekaligus. Fungsi telepon seluler telah berubah dari alat komunikasi menjadi kebutuhan utama mereka sebagaimana halnya makan dan minum.

Memanfaatkan kecanggihan ini, setiap mahasiswa PPKn dapat mengakses internet. Penyerapan informasi terkait isu-isu kewarganegaraan dapat diperoleh lewat media sosial; Facebook,Ttwitter, dan Instagram. Mereka membaca informasi terbaru pada situs online; Kompasiana, Detik.com, Tribun Maluku, Kabar Timur, Ambon Ekspres dan situs lain yang dianggap memiliki kredibilitas. Mereka mengirim tugas melalui gmail, mempelajari berbagai jurnal penelitian ilmiah melalui Google Cendekia, menonton khotbah atau ceramah rohani melalui Youtube, membeli barang melalui aplikasi Zalora atau Sorabel, menggunakan jasa Gojek dan Grab untuk mengantar barang, sampai pada gaya interaksi baru yang dilakukan melalui video call dengan menggunakan aplikasi Zoom, WhatsApp, atau Messenger.

Fenomena ini disebut "disrupsi" oleh beberapa ahli, sebab telah terjadi perubahan besar yang bersifat mendasar dengan sangat cepat tanpa bisa ditahan lajunya (Hapsari, 2019). Era disrupsi telah memberi banyak manfaat yang amat besar bagi warga negara muda sekaligus dampak negatif. Hasil riset menemukan beberapa persoalan. Kesatu, penyebaran informasi dan pengetahuan yang tidak tersaring dengan baik mengakibatkan hoaks terkait SARA dan politik, pornografi, dan jenis kekerasan lainnya dapat terjadi dengan menggunakan perangkat internet.

Kedua, dalam berinteraksi di media sosial, di mana mahasiswa PPKn sebagai pengguna media sosial seringkali memuja sekaligus menghujat, tanpa mengetahui kebenaran konteks informasi. Kesopansantunan dan hormat-menghormati sesama 
warga negara dalam berkomunikasi di media sosial sering diabaikan. Ketiga, munculnya gaya berkomunikasi baru di kalangan warga negara muda yang ditandai dengan penggunaan berbagai istilah dalam bahasa asing, misalnya, via medsos, selfie, zaman now, vc, googling, searching dan istilah lainnya. Berbagai istilah yang digunakan oleh generasi muda tentu menyulikan bahkan menghambat komunikasi dengan generasi yang lebih tua, sebab mereka sulit mencerna makna istilah-istilah itu.

Keempat, intensitas warga negara muda dalam berinteraksi melalui perangkat internet semakin meningkat. Mereka lebih aktif berinteraksi dengan orang yang jauh, namun pasif dengan orang yang ada di depan mata. Jadi, internet mendekatkan yang jauh dan menjauhkan yang dekat. Terhadap persoalan ini, mereka belum menyadari bahwa betapa pun canggihnya teknologi dan informasi yang muncul, kodrat manusia mesti tetap menjadi fundamen bagi penataan kehidupan sosial.

Era disrupsi memperlihatkan secara jelas tentang perubahan yang terjadi secara cepat, masif, dan berdampak besar. Gaya interaksi dengan menggunakan perangkat secara terus menerus adalah fakta yang harus diterima oleh seluruh warga negara. Disrupsi telah menghasilkan kebaruan yang lebih efisien dan menyeluruh serta bersifat destruktif dan kreatif. Dalam pandangan Christensen tentang disrupsi yang kemudian menjadi sangat populer adalah munculnya berbagai aplikasi teknologi informasi. Sementara Fukuyama (2000), mengakui keuntungan atau manfaat yang timbul dari perubahan-perubahan teknologi, sehingga menjadi "masyarakat-informasi" (information society).

Pemanfaatan kecanggihan teknologi dan informasi secara bertanggungjawab untuk tujuan yang membangun adalah hal mutlak yang mesti dilakukan. Warga negara muda yang memiliki pikiran kritis sudah seharusnya mampu menatap perkembangan teknologi lebih cerdas. Fukuyama menjelaskan, warga negara yang dikondisikan oleh kekuatan informasi cenderung menghargai nilai-nilai yang dijunjung tinggi dalam demokrasi, yaitu kebebasan (freedom) dan kesetaraan (equality). Terhadap kedua poin itu, diperlukan kesadaran bersama untuk membuka ruang kebebasan dan kesetaraan dalam berinteraksi maupun berkomunikasi menggunakan perangkat internet.

Lebih lanjut, Rhenald Kasali dalam bukunya Disruption (2017), mengungkapkan bahwa disrupsi tidak hanya berkaitan dengan bisnis, investasi dan keuangan. Namun, berdampak banyak dalam bidang kehidupan seperti pemerintahan, politik, dunia hiburan, dan sosial. Dicontohkan dalam buku tersebut bahwa perubahan yang terjadi mulai dari hadirnya telegraf menjadi telepon kabel, kemudian berubah menjadi ponsel biasa dan berubah lagi menjadi smart phone yang telah dianggap sebagai kebutuhan primer manusia.

Perubahan teknologi yang mengakibatkan apa yang disebut Joseph Schumpeter sebagai "creative destruction" di pasar, niscaya juga mendisrupsi relasirelasi sosial. Selama IPTEK masih terus berkembang, maka selama itu pula disrupsi akan terjadi. Namun dampak negatif disrupsi mesti diatasi. Fukuyama (2000), berasumsi agar setiap warga negara menata kembali kehidupan sosial, maka perhatian perlu diarahkan kepada dua kapasitas manusiawi. Artinya kesadaran 
akan kodrat manusia dan kecenderungan manusia untuk mengorganisasi diri.

Apapun persoalannya, paling tidak lahirnya era disrupsi telah membantu kita untuk melihat dengan lebih tajam gelombang perubahan yang sedang melanda dunia dan masyarakat dan untuk menanggapi secara positif perubahan-perubahan tersebut. Walaupun disrupsi bukanlah segalanya (Ohoitimur, 2018). Seperti halnya dengan postmodernisme, disrupsi terutama menjadi instrumen konseptual untuk memahami perubahan-perubahan yang sedang terjadi karena perkembangan teknologi informasi.

\section{Literasi Media Menjadi Preferensi Warga Negara Muda}

Di era disrupsi, pengetahuan tentang literasi media menjadi preferensi bagi warga negara muda untuk melatih keterampilan berpikir kritis sehingga menghasilkan keterampilan interpretasi, analisis, dan evaluasi berita. Pada gilirannya literasi media dapat membantu mereka untuk menentukan kebenaran suatu berita. Literasi media mengaktifkan akal sehat, namun menonaktifkan kepentingan kelompok tertentu yang diseludupkan melalui berita. Kebenaran berita ditelusuri melalui tahapan yang mendalam sehingga berita palsu dapat diketahui secara mudah.

Penelitian terkait pengetahuan literasi media pada mahasiswa PPKn menemukan beberapa hal diantaranya. Kesatu, kebenaran sebuah berita di media didalami menggunakan rumus tanya $5 \mathrm{~W}+1 \mathrm{H}$ (what, where, when, who, why and how). Berita digali secara utuh lewat pertanyaan-pertanyaan yang diajukan. Tindakan ini menjadikan mereka sebagai konsumen media yang aktif ketika menemui sebuah berita. Mereka dapat menyadari isi pesan di media kemudian mengkritisi jika dianggap mengandung resiko.

Kedua, penelusuran terhadap fakta dan data dari sumber lain untuk memastikan kebenaran berita. Media yang dianggap paling kredibel seperti Kompas TV, TV One, Metro TV, dan Net TV maupun Kompasiana, Detik.com, Tribun Maluku, Kabar Timur, dan Ambon Ekspres sebagai media online dapat dijadikan rujukan dalam mengonfirmasi kebenaran berita. Di sini, mereka dapat menemukan dan menyingkapkan isi berita yang sebelumnya belum dimengerti secara jelas. Tindakan ini sejalan dengan teori korespondensi yang menegaskan bila sebuah pernyataan tidak sesuai dengan, atau tidak merujuk fakta yang sahih, maka pernyataan tersebut bohong (Suryadi, 2007). Teori ini menjadi acuan bagi mereka saat melakukan konfirmasi terhadap suatu berita.

Ketiga, setelah mengetahui kebenaran berita, mereka berpartisipasi aktif untuk menjelaskan kebenarannya secara gamblang kepada orang lain yang bertanya tentang suatu berita. Tindakan itu termasuk dalam kategori literasi menurut National Leadership Conference on Media Education tentang komunikasi di mana seseorang mampu mengkomunikasikan pesan yang diterima dari media dalam bentuk apa saja kepada orang lain secara benar (Hobbs, 1999).

Satu aspek penting literasi media ini adalah perubahan cara pandang terhadap media (Buckingham, 2001), sebab media memiliki fungsi edukatif atau pun non edukatif bergantung dari muatan pesan informasi yang disampaikannya (Winataputra, 2012). Akan tetapi, media dipercaya memiliki kekuatan yang sangat 
besar untuk membentuk opini dan kepercayaan, mengubah kebiasaan hidup, dan membentuk sikap berdasarkan kontrol dari warga (Bauer, 1960).

Dalam gaya konsumsi budaya populer pengetahuan tentang literasi media menjadi sebuah keharusan bagi warga negara. Kajian tentang literasi media dirasakan sangat penting dilakukan (Livingstone, 2004; Mihailidis, 2006). Langkah ini membuat warga negara muda secara kritis melihat dan membedakan informasi yang baik dan buruk di media (Hobbs, 1999). Selain itu, literasi media memberikan publik kontrol lebih daripada sekedar interpretasi atas teks media (Potter, 2018). Akhir-akhir ini pengelola media di tanah air lebih bertanggung jawab pada pemilik media yang memodali usaha media daripada warga yang menjadi khalayak media tersebut.

Beberapa media di tanah air telah dikuasai oleh perusahaan-perusahaan yang berpengaruh. Tentu sangat menentukan pilihan berita, cara penyampaian, serta besarnya liputan. Pada umumnya, perusahaan-perusahaan itu bertujuan mencari untung. Karena itu, berita-berita yang tidak menguntungkan para pemilik media tersebut biasanya tidak akan diliput. Persoalan lainnya adalah sebagian besar media sosial telah terkontaminasi dengan kepentingan politik dan ekonomi. Akibatnya berita yang diproduksi oleh jurnalis sarat dengan kepentingan.

Suryadi (2007) mengeluhkan berita baik kurang diminati karena telah terjadi persaingan yang amat ketat antarmedia. Berita terkait kejadian buruk lebih dikejar dan mendapat porsi cukup besar dalam pemberitaan sementara kejadian baik hanya menjadi berita biasa atau bahkan tidak diberitakan di media. Persoalan ini menjadi pelajaran penting bagi setiap warga negara, bahwa kebebasan media dalam menyampaikan pendapat secara bertanggung jawab telah gagal dilakukan.

Kemelekan warga negara muda terhadap beragam berita di media menjadi preferensi untuk menyelamatkan mereka dari terpaan berita palsu. Pada dasarnya literasi media dijadikan sebagai upaya pembelajaran bagi khalayak media sehingga mereka menjadi khalayak yang berdaya hidup di tengah dunia yang sesak media (Yosal, 2009). Karena itu, perlu pembekalan setiap warga negara muda dengan pengetahuan tentang literasi media.

\section{SIMPULAN}

Berdasarkan tahapan deskripsi hasil penelitian, pembahasan, dan analisis terhadap keseluruhan bagian tentang tema dalam tulisan ini, maka simpulan umum yang dapat ditarik adalah literasi media menjadi jaminan kebutuhan informasi dan gaya interaksi yang efektif maupun efisien di era disrupsi. Kemampuan menginterpretasi, menganalisis, dan mengevaluasi informasi merupakan ruang lingkup pengetahuan literasi media. Hal ini pada gilirannya dapat membantu mahasiswa PPKn sebagai warga negara muda untuk melihat lebih kritis kebenaran informasi di media. Melalui literasi media mahasiswa PPKn dapat berpartisipasi aktif dalam mengontrol beragam pesan di media sehingga dapat menyelamatkan mereka dari terpaan berita bohong.

Literasi media diperlukan sebagai upaya dalam mencerdaskan warga negara muda agar mereka dapat menjadi konsumen media kritis dan kreatif dalam memandang sebuah berita. Sebelum mengonsumsi berita mereka dapat melakukan 
penelusuran terhadap fakta dan data pada media yang terpecaya. Berita digali secara utuh lewat pertanyaan-pertanyaan yang diajukan dengan menggunakan rumus $5 \mathrm{~W}+1 \mathrm{H}$. Melalui langkah itu, mereka dapat menggiring beragam informasi di media secara utuh mulai dari awal hingga akhir kemudian mengkritisi jika dianggap mengandung resiko. Maka, kepada setiap warga negara yang hidup di era disrupsi agar menjadikan literasi media sebagai preferensi di era disrupsi.

\section{REFERENSI}

Bauer, R. A. (1960). Consumer behavior as risk taking. Chicago, IL, 384-398.

Buckingham, D. (2001). Media Education: A Global Strategy for Development A policy paper prepared for UNESCO Sector of Communication and Information. Institute of Education, University of London, England. Retrieved June, 30, 2006.

Christensen, C. M., Baumann, H., Ruggles, R., \& Sadtler, T. M. (2006). Disruptive innovation for social change. Harvard Business Review, 84(12), 94.

Fukyama, F. (2000). The Great Disruption: Human Nature and Reconstitution of Social Order. Profile Books.

Goldsmith, B., Cunningham, S., \& Dezuanni, M. (2017). Screen production for education: Digital disruption in an 'ancillary'market. Media International Australia, 162(1), 65-77.

Hapsari, D. (2019). Tantangan Perpustakaan Perguruan Tinggi di Era Disrupsi. Pustakaloka, 11(1), 151-160.

Hobbs, R. (1999). The seven great debates in the media literacy movement.

Kasali, R. (2017). Disruption, PT. Gramedia Pustaka Utama, Jakarta.

Livingstone, S. (2004). What is Media Literacy. Intermedia.

McLuhan, M. (1964). McLuhan Understanding Media The extensions of man London and New York. Basieexpsispittedu. https://doi.org/10.2307/2711172

Mihailidis, P. (2006). Media literacy in journalism/mass communication education: Can the United States learn from Sweden? Journalism \& Mass Communication Educator, 60(4).

Miles, M. B., Huberman, A. M., \& Saldana, J. (2014). Qualitative data analysis: A methods sourcebook. Sage.

Murdiono, M., Wahab, A. A., \& Maftuh, B. (2014). Building a global perpective of young citizens having. Jurnal Pendidikan Karakter, 4(2), 148-159.

Ohoitimur, J. (2018). Disrupsi: Tantangan Bagi Perkembangan Ilmu Pengetahuan dan Peluang Bagi Lembaga Pendidikan Tinggi. Respons, 23(02), 143-166.

Potter, W. J. (2018). Media literacy. Sage Publications.

Prasetiyo, W. H. (2016). Darurat literasi media dalam digital citizenship: Satu gagasan menuju warga negara melek informasi. Pendidikan Kewarganegaraan Sebagai Bidang Keilmuan Dan Program Pendidikan Dalam Konteks Penguatan Daya Saing Lulusan, Bandung.

RAHMAWATI, Y. (2015). Kastrasi Frekuensi Publik: Media Literacy Era Budaya Populer. Jurnal Komunikasi, 9(2), 119-130.

Shrum, L. J., Ismanto, A., \& Bagus, M. (2010). Psikologi media entertainment. JALASUTRA. 
Suryadi, K. (2007). Media Massa dan "Political Literacy": Pemanfaatan Berita Politik di Kalangan Remaja. Mediator: Jurnal Komunikasi, 8(1), 77-82.

Widhana, Dieqy Hasbi. (16 Desember 2016). Pemilik Pos Metro, Abdul Hamdi: "RataRata Penghasilan Kita Rp25-30 Juta." tirto.id: Wawancara. https:/ / tirto.id/ratarata-penghasilan-kita-rp25-30-juta-b9WS

Winataputra, U. S. (2012). Pendidikan kewarganegaraan dalam perspektif pendidikan untuk mencerdaskan kehidupan bangsa: gagasan, instrumentasi, dan praksis. Bandung: Widya Aksara Press Pemerintahan, 1(2), 612-625.

Yosal, I. (2009). Literasi Media. Apa, Mengapa, Bagaimana, Bandung: Simbiosa Rekatama Media. 